\title{
Innate Phagocytosis and P2X7 Receptor Function: a Comparison of Endophthalmitis Patients and Population Controls
}

\author{
Andrew Hurley \\ Monash University

\section{Xin Huang} \\ University of Melbourne

\section{Baijun Gu} \\ University of Melbourne

\section{Penelope Allen} \\ University of Melbourne
}

Rosie Claire Hewitt Dawkins ( $\square$ rosie.dawkins@post.harvard.edu )

University of Melbourne https://orcid.org/0000-0002-7927-8851

Research article

Keywords: Endophthalmitis, Innate immunity, Phagocytosis, P2X7 receptor

Posted Date: November 26th, 2019

DOl: https://doi.org/10.21203/rs.2.17073/v2

License: (c) (1) This work is licensed under a Creative Commons Attribution 4.0 International License. Read Full License 
The authors have withdrawn this preprint from Research Square 